\title{
Customs officers in relation to viral infections, tuberculosis, psittacosis and environmental health risk (Review)
}

\author{
MARIA MAMMA and DEMETRIOS A. SPANDIDOS
}

Department of Virology, School of Medicine, University of Crete, 71110 Heraklion, Greece

Received September 28, 2018; Accepted November 27, 2018

DOI: $10.3892 /$ etm.2018.7077

\begin{abstract}
Customs Service is a financial authority responsible for controlling the flow of importation and exportation goods in each country and for collecting the relevant taxes. Customs officers are considered as 'high-demand' and 'high-responsibility' governmental officials, which constitute members of multidisciplinary teams at the local, as well as international level and collaborate with different authorities, including medical officers. Despite limited data in the medical literature, customs officers are considered as a 'high-risk' occupational group for infections and environmental health risk. During the severe acute respiratory syndrome (SARS) and influenza A/H1N1 pandemic outbreaks in 2003 and 2009, respectively, customs officers had a fundamental front-line input in the establishment of the recommended at that time border measures. In Belgium in 1994, a psittacosis outbreak occurred in customs officers following their exposure to illegally imported parakeets. During the recent increased immigration proceedings, customs officers have been involved in detaining unauthorized populations for various infectious diseases, such as tuberculosis, varicella and measles. Occupational risk for customs officers also includes noise-induced hearing loss, exposure to diesel engine emission and stored tobacco and occupational stress due to their increased time-schedule and decision-making duties. In this review, we discuss customs officers' occupational risk towards environmental and infectious factors, including viral infections, tuberculosis and psittacosis.
\end{abstract}

\section{Contents}

1. Introduction

2. Customs officers and viral infections

Correspondence to: Professor Demetrios A. Spandidos, Department of Virology, University of Crete School of Medicine, Voutes, 71110 Heraklion, Greece

E-mail: spandidos@spandidos.gr

Key words: customs officers, viral infections, severe acute respiratory syndrome, influenza, psittacosis, tuberculosis, varicella, measles, health risk
3. Customs officers and tuberculosis

4. Customs officers and psittacosis

5. Customs officers and occupational risk

6. Conclusions

\section{Introduction}

Customs Service in each country is a financial authority responsible for controlling the importation or exportation flow of goods and for collecting the relevant taxes/tariffs (1). Moreover, the Customs Code contains provisions that govern customs officers in their fight against drug crimes and the proceeds of such crimes (2). Although each country has its own laws and regulations, which its Customs Service authorities enforce, in most countries, Customs Service is attained through government agreements and international laws. Customs officers are considered as 'high-demand' and 'high-responsibility' governmental officials, which constitute members of multidisciplinary teams at the local, as well as international level and collaborate with different authorities, including medical officers $(3,4)$. Their careers are characterized with professionalism and involve multiple tasks, including securing the borders and preventing drug smuggling, while enforcing immigration laws, protecting agriculture, and ensuring trade compliance, and preventing illegal entry of individuals and prohibited goods. Customs officers are also involved in detecting and preventing terrorists and terrorist weapons from entering the country, as well as in preventing the illegal trafficking of individuals, narcotics and contraband. Customs officers can work at airports, at docks, or any major land port of entry.

Recently, the increasing patterns in volume and complexity of worldwide travelling and trade have strengthened customs officers' role at the front-line of borders checking. Following the passage of the Illegal Immigration Reform and Immigrant Responsibility Act of 1996 and the creation of the Immigration and Customs Enforcement (ICE) agency in the US following the attacks of September 11, 2001, Customs Service's responsibilities in different countries, such as the European Union countries, the US and Canada, have increased substantially. The recent immigration crisis has also resulted in increasing ICE activities, such as raids, detention and deportation, which have been the subject of recent reports on how they affect the health and well-being of travelers, including children (5-7). 
However, despite the fact that customs officers are considered as a 'high-risk' population group for infections and environmental/occupational accidents, available medical literature on this issue and the occupational risk associated with their profession remains limited. The purpose of this review was to investigate data on customs officers published in PubMed over the past 30 years, emphasizing their 'high-risk' characteristics in relation to infections and occupational health risk. We searched PubMed (MEDLINE) using the key words 'customs', 'borders', 'customs service', 'customs personnel', 'customs workers' and 'customs officials'. We identified studies evaluating customs officers in relation to infectious diseases and occupational risk. The purpose of this review was to categorize these studies as shown in Table I and to present an overview of all up-to-date available medical data on customs officers.

\section{Customs officers and viral infections}

Severe acute respiratory syndrome (SARS). In response to the recent SARS pandemic of 2003, a number of countries have instituted border measures as a means of inhibiting or attenuating its international spread (8-12). These measures consisted of a combination of border entry screening programs to detect arriving travelers with symptoms of SARS, quarantine, isolation and communications. Despite the limited effectiveness of these screening measures, they were resource-intensive and innovative at that time, following modern international travel. The contribution of customs officers during these border control measures was significant. Notably, the initial lack of strategic plans for this newly emerging disease resulted in Canadian customs officers nationwide threatening to 'walk off the job' over concerns that they might contract SARS from passengers arriving from Asia (13). The 11,500-member union petitioned the Customs and Revenue Agency to meet a list of demands regarding SARS, including customs officers to the list of 'high-risk' health care providers, including medical doctors, nurses and paramedics.

Pandemic A/H1N1 influenza. In 2009, customs officers played a significant role in the international public health control measures implemented to limit the spread of pandemic A/H1N1 influenza. These measures included the containment triage of febrile patients at front-line healthcare settings, the admission and isolation of confirmed cases, mandatory quarantine orders for close contacts, temperature screening at border entry points and mitigation strategies (14). Moreover, recommended health policies from many countries included customs officers to the 'high-priority' professional groups for pandemic $\mathrm{A} / \mathrm{H} 1 \mathrm{~N} 1$ influenza vaccination. The decision analytical computational simulation of economic modelling, developed by the University of Crete School of Medicine in collaboration with the Athens University of Economics and Business (AUEB), demonstrated that when implementing a pandemic A/H1N1 influenza vaccination program among customs officers in Greece with a participation rate of only $30 \%$, influenza vaccination was not cost-saving in any of the studied influenza scenarios (15). When the participation rate reached $100 \%$, the program was cost-saving, when the influenza attack rate was $30 \%$ and the symptomatic rate $65 \%$. However, in that study, the estimated mean net cost-benefit value in 2009/2010 period was -7.3 euros/customs officer.

Hepatitis B. Customs officers are in excess risk of hepatitis B virus infection as a consequence of their occupational exposure to human blood and penetrating injuries. However, in 1987, a cross-sectional study by Bandaranayake et al (16) from the New Zealand Communicable Disease Centre in Porirua in New Zealand, failed to demonstrate any significant association between customs officers' occupational variables and the prevalence of hepatitis B. Notably, in that study, which evaluated the hepatitis B markers of 1,026 customs officers at the New Zealand Customs Department, the prevalence ratio for customs officers compared with the civilians was 0.49 (95\% CI 0.34-0.70). Further analysis of these data by Blakely et al (17) estimated the population hepatitis B surface antigen (HBsAg) carrier prevalence for adults in New Zealand.

Varicella and herpes zoster. Varicella zoster virus (VZV) is the cause of varicella and herpes zoster, which continue to plague children and adults worldwide (18). Although public health programs have implemented vaccination against VZV and have resulted in a significant decrease in the prevalence and sequelae of these diseases, outbreaks still occur. Recently, these outbreaks have been associated with the low protection levels against VSV in migrants and refugees coming to Europe and emphasize the need for stringent vaccination strategies (19). Additionally, the continuous surveillance of varicella and herpes zoster is required in order to identify any changes in the current epidemiological presentation of the diseases. During the 2014/2015 period, among 400 adult detainees at the US ICE in California, serological testing for VZV IgG revealed that $12 \%$ were susceptible to varicella (20); among these detainees, vaccination against VZV was offered aiming to reduce the existing varicella transmission risk.

Customs officers and measles. On May 2016, a detainee at a US ICE in Arizona, which was housing 1,425 detainees and employing 510 staff members, was diagnosed with measles (21); the following day, a second case of measles in a staff member was also confirmed by quantitative (real-time) polymerase chain reaction (qPCR). Outbreak control measures were initiated with the administration of the measles-mumps-rubella (MMR) vaccine to all detainees housed at the facility and with the isolation of the detainee patient. Epidemiological investigations by local and state health departments identified 31 total cases of measles in 22 detainees and nine staff members. Without any doubt, this finding highlights the necessity for primary reliance on supplementary immunization activities (SIAs) to assure two doses of measles-containing vaccine (MCV) administration in customs officers, which constitute a 'high-risk' occupational group for measles transmission (22).

\section{Customs officers and tuberculosis}

Customs officers are frequently involved in detaining unauthorized aliens during immigration proceedings; detained individuals are considered as a 'high-risk' population for tuberculosis. In the study by Schneider and Lobato (23), during the 
Table I. Customs officers in relation to infections and occupational health risk.

Viral infections
SARS
A/H1N1 influenza
Hepatitis B
Varicella/herpes zoster
Measles
Tuberculosis
Psittacosis
Occupational risk
Noise-induced hearing loss
Diesel engine emission
Exposure to stored tobacco
Occupational stress

SARS, severe acute respiratory syndrome.

2004/2005 period, 218 detainees at the US ICE were screened positive for tuberculosis and were reported to the Division of Immigration Health Services (DIHS). Among these patients, $58.3 \%$ had Mycobacterium tuberculosis-positive sputum cultures, $32.1 \%$ had acid-fast bacilli-positive sputum smears and $16.5 \%$ were symptomatic at diagnosis. The majority of these patients originated from Mexico, Honduras, Guatemala and El Salvador, and after spending an average of 82.6 days in treatment, they were repatriated.

\section{Customs officers and psittacosis}

Psittacosis - the term 'psittacosis' is derived from the Hellenistic ancient Greek word for parrots, 'psittakos' ( $\psi \iota \tau \tau \alpha \kappa o ́ \varsigma)$ or 'psit-

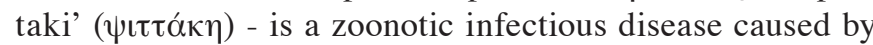
the obligatory intracellular bacterium Chlamydia psittaci; in humans, Chlamydia psittaci can cause infection mainly presented as community-acquired pneumonia $(24,25)$. This bacterium can infect parrots, parakeets, canaries and other avian species (e.g., turkeys, pigeons and ducks) and is considered a financially significant pathogen for poultry farming. Psittacosis is an occupational disease of zoo and pet-shop employees, poultry farmers and ranchers. The illegal bird trade can be a possible source of zoonotic infections (26), which can potentially include customs officers to the list of 'high-risk' occupations for Chlamydia psittaci.

In Belgium, a psittacosis outbreak occurred in customs officers following their exposure to illegally imported parakeets, was published by Dr Koen de Schrijver, Health Inspector in Antwerp, Belgium (27,28). In March 1994, health authorities in Antwerp, Belgium, were informed that a member of a team of 15 customs officers had been admitted to hospital with Chlamydia psittaci-induced pneumonia. His symptoms began at 10 days following his exposure to parakeets that had been imported illegally by an Indian sailor. He was 54 years of age and his diagnosis was based on the presence of antibodies against Chlamydia psittaci in his blood analyses. A necropsy of one of these parakeets revealed pericardial lesions typical of Chlamydia psittaci infection. Further investigation revealed that among the team of customs officers, who had possibly been exposed to the birds, another 6 customs officers, who had been in contact with the birds while they were held in the customs office, developed atypical pneumonia; in two of these cases, psittacosis was confirmed serologically. The risk of contracting psittacosis was 2.8-fold higher in officers exposed for $>2 \mathrm{~h}$ to parakeets than for those briefly exposed. This outbreak emphasized the need for the preventive measures in Customs Service for the customs officers handling suspicious import or export goods. These measures included relevant procedures for handling, transporting and captivity of confiscated birds, supply of protective clothing for customs officers at risk of potentially infectious contact, their health education and their strengthened medical surveillance in collaboration with occupational health services.

\section{Customs officers and occupational risk}

Customs officers and noise-induced hearing loss. Noise-induced hearing loss is one of the most common forms of sensorineural hearing loss with significant health, as well as economic impact (29). It has been recognized as an occupational disease, amongst copper workers from hammering on metal, blacksmiths in the 18th century and shipbuilders or 'boilermakers' after the Industrial Revolution (30). For environmental exposure, hearing loss can be caused by long-term, continuous exposure to noise; however, it can also result from single or repeated sudden noise exposure, which is generally referred to as acoustic trauma. Exposure to excessive noise is the most common preventable cause of hearing loss. Exposure to sudden impulse noise is more detrimental than exposure to steady state noise. Customs officers, particularly the group of radar operators, gunsmiths and shooting instructors, have been proposed to be vulnerable to noise-induced hearing loss (31). Using ear protection can prevent needless and permanent damage to hearing and constitute the first-line of defense of these preventative otopathies.

Customs officers and diesel engine emission. In 2003, a five-year survey of Swiss customs officers by Glück et al (32), evaluated the adverse effects of the chronic exposure of customs officers to diesel engine emission (DEE). Their study recruited 194 non-smoking customs officers, from where brush nasal cytology probes were taken twice a year over a period of 5 years. Among these officers, 136 were solely occupied with the clearing of diesel trucks, where measured DEE concentrations varied between 31 and $60 \mu \mathrm{g} / \mathrm{m}^{3}$ and benzo[a]pyrene concentrations were between 10 and $15 \mathrm{ng} / \mathrm{m}^{3}$. In contrast to those working only in the office, customs officers exposed to DEE were diagnosed with chemical-induced chronic inflammation of their nasal mucosa, characterized by clear goblet cell hyperplasia with increased metaplastic and dysplastic epithelia and an increase in leukocytes. Additionally, the findings of metaplastic and dysplastic nasal epithelia in the exposed officers may indicate a genotoxic effect of chronic DEE exposure in humans.

Customs officers and exposure to stored tobacco. In 2008, Mackiewicz et al (33) from the Medical University of Lublin, in Lublin, Poland, reported work-related respiratory symptoms, 
in two customs officers employed in two depositories of confiscated cigarettes, of which one exhibited signs of dampness. These symptoms included dyspnea, cough, fever, tiredness and malaise. Microbiological sampling of the air and the cigarettes stored in a damp depository revealed the presence of potentially pathogenic fungi and bacteria and the biochemical markers of bacterial lipopolysaccharide and fungal biomass. The Penicillium species ( $P$. simplicissimum, $P$. inflatum, $P$. commune) dominated in the damp depository, while in the other one Aspergillus fumigatus was prevalent. The patients under study did not exhibit a specific sensitization to microbial allergens in the precipitin test, the test for inhibition of leukocyte migration and the bronchial provocation challenge, apart from a weak reaction to fungal allergens in the test for inhibition of leukocyte migration. Moreover, one patient responded with subjective symptoms following exposure to the inhalation of increased doses of the $P$. simplicissimum antigen. Both cases were diagnosed as a specific form of organic dust toxic syndrome (ODTS). It was hypothesized that the symptoms were evoked most probably by the non-specific action of low molecular fungal metabolites, such as mycotoxins or volatile organic compounds (VOCs), with the possible contribution of bacterial endotoxin. However, as there is no a direct evidence to support this presumption and the effects of nicotine and other tobacco constituents cannot be excluded, further studies are required in order to elucidate the etiopathogenesis of the disorders associated with the exposure to stored tobacco.

Customs officers and occupational stress. Customs officers belong to 'high-demand' occupational groups that may overburden their bodily capacities, safety or health and are vulnerable to occupational stress (34). As it has been demonstrated in other 'high-demand' groups, occupational stressors contribute to organizational inefficiency, high staff turnover, absenteeism that is mainly due to sickness, decreased quality and quantity of practice, increased costs of healthcare, and decreased job satisfaction (35). Customs officers experience higher rates of job stress and burnout due to their increased decision-making responsibilities. Recently, Pachur and Marinello (36) from the Max Planck Institute for Human Development in Berlin, Germany, studied airport customs officers in order to evaluate how expertise impacts the selection of decision strategies. In their study, the majority of the customs officers were best described by the non-compensatory heuristic, whereas the majority of the novices were best described by a compensatory strategy. Experts often rely on one-reason decision making and that expert-novice differences in strategy selection may reflect a response to the internal representation of the environment.

The study by Prunier et al (37) performed in Paris, France, compared the effects of different shift schedules used by French Customs Units. Notably, the officers working 4x6-h shifts reported a high proportion of sleep difficulties and digestive disturbances; their situation was very similar to that of officers working 3x8-h shifts and contrasted markedly with that of officers working $2 \times 12$-h shifts and day workers. This was attributed to the irregularity of eating habits imposed by four different shifts, the greater number of working days in the week, and the frequent assignment of two shifts on the same day were concluded as critical etiological factors.
Further logistic regression analyses on the health aspects of the customs officers, highlighted the dominating effect of the $3 \times 8-h$ and $4 \times 6-h$ schedules on the occurrence of health problems, but also indicated marked effects for confrontation with travelers (38). The conflictual relations with travelers had the largest and most marked influence on the area of sleep and digestive and cardiovascular problems.

\section{Conclusions}

To date, customs officers have been well-described as a 'high-risk' occupational group due to their exposure to several infections, including SARS, A/H1N1 influenza, hepatitis B, varicella, measles, tuberculosis and psittacosis. In 2003, during the SARS pandemic outbreak, customs officers contributed to the institution of border control measures, inhibiting or attenuating its international spread. Similarly, in 2009, customs officers played a significant role in the international public health control measures implemented to limit the spread of pandemic. The environmental risk for customs officers includes noise-induced hearing loss, exposure to diesel engine emission and stored tobacco and occupational stress due to their increased time-schedule and decision-making duties. Without any doubt, further assessment of the health status of customs officers is required in order to evaluate and decrease their environmental and occupational risk.

\section{Acknowledgements}

Not applicable.

\section{Funding}

No funding was received.

\section{Availability of data and materials}

Not applicable.

\section{Authors' contributions}

MM and DAS both contributed to the conception and design of the study. MM was involved in the literature search pertaining to this review. Both authors contributed equally to the writing and reviewing of the manuscript and both authors have read and approved the final manuscript.

\section{Ethics approval and consent to participate}

Not applicable.

\section{Patient consent for publication}

Not applicable.

\section{Competing interests}

DAS is the Editor-in-Chief for the journal, but had no personal involvement in the reviewing process, or any influence in terms of adjudicating on the final decision, for this article. 


\section{References}

1. Cutting PD: Drug problems through the eyes of the investigation division of H M Customs \& Excise. Med Leg J 48: 119-128, 1980.

2. Jacquemart C: An assessment of legal measures to trace, freeze and confiscate the proceeds of drug crimes in France: The Customs viewpoint. Bull Narc 36: 43-50, 1984.

3. Zimmers TE: Body-cavity concealment of contraband Cooperation between the US Customs Service and the ED. Am J Emerg Med 4: 37-39, 1986.

4. Eggertson L: Only five doctors in Canada can assess mental status for US Customs and Border Protection. CMAJ 186: 98 , 2014.

5. McLeigh JD: How do Immigration and Customs Enforcement (ICE) practices affect the mental health of children? Am J Orthopsychiatry 80: 96-100, 2010.

6. Hacker K, Chu J, Leung C, Marra R, Pirie A, Brahimi M, English M, Beckmann J, Acevedo-Garcia D and Marlin RP: The impact of immigration and customs enforcement on immigrant health: Perceptions of immigrants in Everett, Massachusetts, USA. Soc Sci Med 73: 586-594, 2011.

7. Hacker K, Chu J, Arsenault L and Marlin RP: Provider's perspectives on the impact of immigration and customs enforcement (ICE) activity on immigrant health. J Health Care Poor Underserved 23: 651-665, 2012.

8. Samaan G, Patel M, Spencer J and Roberts L: Border screening for SARS in Australia: What has been learnt? Med J Aust 180: 220-223, 2004.

9. St John RK, King A, de Jong D, Bodie-Collins M, Squires SG and Tam TW: Border screening for SARS. Emerg Infect Dis 11: 6-10, 2005

10. Selvey LA, Antão C and Hall R: Entry screening for infectious diseases in humans. Emerg Infect Dis 21: 197-201, 2015.

11. Glass K and Becker NG: Evaluation of measures to reduce international spread of SARS. Epidemiol Infect 134: 1092-1101, 2006

12. Gaber W, Goetsch U, Diel R, Doerr HW and Gottschalk R: Screening for infectious diseases at international airports: The Frankfurt model. Aviat Space Environ Med 80: 595-600, 2009.

13. Tyshenko MG and Paterson C: SARS Unmasked: Risk communication of pandemics and influenza in Canada. McGill-Queen's University Press, Montreal, 2010.

14. Tay J, Ng YF, Cutter JL, James L and Influenza A: Influenza A (H1N1-2009) pandemic in Singapore - public health control measures implemented and lessons learnt. Ann Acad Med Singapore 39: 313-12, 2010

15. Mamma M and Spandidos DA: Economic evaluation of the vaccination program against seasonal and pandemic $\mathrm{A} / \mathrm{H} 1 \mathrm{~N} 1$ influenza among customs officers in Greece. Health Policy 109: 71-77, 2013

16. Bandaranayake DR, Salmond CE and Tobias MI: Occupational risk of hepatitis B for police and customs personnel. Am J Epidemiol 134: 1447-1453, 1991.

17. Blakely T, Salmond C and Tobias M: Hepatitis B virus carrier prevalence in New Zealand: Population estimates using the 1987 police and customs personnel survey. N Z Med J 111: 142-144, 1998.

18. Edmunds WJ and Brisson M: The effect of vaccination on the epidemiology of varicella zoster virus. J Infect 44: 211-219, 2002

19. Jablonka A, Happle C, Wetzke M, Dopfer C, Merkesdal S Schmidt RE, Behrens GMN and Solbach P: Measles, Rubella and Varicella IgG Seroprevalence in a Large Refugee Cohort in Germany in 2015: A Cross-Sectional Study. Infect Dis Ther 6 : 487-496, 2017.

20. Varan AK, Lederman ER, Stous SS, Elson D, Freiman JL, Marin M, Lopez AS, Stauffer WM, Joseph RH and Waterman SH: Serological Susceptibility to Varicella Among U.S. Immigration and Customs Enforcement Detainees. J Correct Health Care 24: $84-95,2018$
21. Venkat H, Kassem AM, Su CP, Hill C, Timme E, Briggs G, Komatsu K, Robinson S, Sunenshine R, Patel M, et al; Measles Investigation Team: Notes from the Field: Measles Outbreak at a United States Immigration and Customs Enforcement Facility - Arizona, May-June 2016. MMWR Morb Mortal Wkly Rep 66: 543-544, 2017.

22. Orenstein WA, Hinman A, Nkowane B, Olive JM and Reingold A: Measles and Rubella Global Strategic Plan 2012-2020 midterm review. Vaccine 36 (Suppl 1): A1-A34, 2018.

23. Schneider DL and Lobato MN: Tuberculosis control among people in U.S. Immigration and Customs Enforcement custody. Am J Prev Med 33: 9-14, 2007.

24. Radomski N, Einenkel R, Müller A and Knittler MR: Chlamydia-host cell interaction not only from a bird's eye view: Some lessons from Chlamydia psittaci. FEBS Lett 590: 3920-3940, 2016

25. Hogerwerf L, DE Gier B, Baan B and VAN DER Hoek W: Chlamydia psittaci (psittacosis) as a cause of community-acquired pneumonia: A systematic review and meta-analysis. Epidemiol Infect 145: 3096-3105, 2017.

26. Rosen GE and Smith KF: Summarizing the evidence on the international trade in illegal wildlife. EcoHealth 7: 24-32, 2010.

27. De Schrijver K: A psittacosis outbreak in Belgian customs officers. Euro Surveill 0: 3, 1995.

28. De Schrijver K: A psittacosis outbreak in customs officers in Antwerp (Belgium). Bull Inst Marit Trop Med Gdynia 49: 97-99, 1998.

29. Alberti PW, Symons F and Hyde ML: Occupational hearing loss. The significance of asymmetrical hearing thresholds. Acta Otolaryngol 87: 255-263, 1979.

30. Le TN, Straatman LV, Lea J and Westerberg B: Current insights in noise-induced hearing loss: A literature review of the underlying mechanism, pathophysiology, asymmetry, and management options. J Otolaryngol Head Neck Surg 46: 41, 2017.

31. Attili F, Chiusano A, Giangiacomo G, Grasso $S$ and Santonastaso F: The incidence of otopathies in a group of radar operators, gunsmiths and shooting instructors of the Customs Service. G Ital Med Lav 12: 109-122, 1990 (In Italian).

32. Glück U, Schütz R and Gebbers JO: Cytopathology of the nasal mucosa in chronic exposure to diesel engine emission: A five-year survey of Swiss customs officers. Environ Health Perspect 111: 925-929, 2003

33. Mackiewicz B, Skórska C, Krysińska-Traczyk E, Larsson L, Szponar B, Milanowski J, Czekajska-Chehab E, Sitkowska J, Cholewa G, Szymańska J, et al: Respiratory disorders in two workers of customs depositories occupationally exposed to mouldy tobacco. Ann Agric Environ Med 15: 317-322, 2008.

34. Sluiter JK: High-demand jobs: Age-related diversity in work ability? Appl Ergon 37: 429-440, 2006.

35. Kazmi R, Amjad S and Khan D: Occupational stress and its effect on job performance. A case study of medical house officers of district Abbottabad. J Ayub Med Coll Abbottabad 20: 135-139, 2008.

36. Pachur T and Marinello G: Expert intuitions: How to model the decision strategies of airport customs officers? Acta Psychol (Amst) 144: 97-103, 2013.

37. Prunier S, Gadbois $C$ and Foret J: Unfavorable consequences of six-hour shiftwork. Int J Occup Environ Health 3 (Suppl 2): S53-S60, 1997.

38. Prunier-Poulmaire S, Gadbois C and Volkoff S: Combined effects of shift systems and work requirements on customs officers. Scand J Work Environ Health 24 (Suppl 3): 134-140, 1998. 